\title{
Lipase-Catalyzed Synthesis and Characterization of 6-O-(11-Dodecenoic)-glucose Ester in Ionic Liquids ${ }^{*}$
}

\author{
Ping-Jia Yao ${ }^{1}$, Guang-Jun Huang ${ }^{2,3}$, Wei Yan ${ }^{2}$, Xin Zhang ${ }^{2}$, Qunliang Li ${ }^{2}$, Yuan-An Wei ${ }^{1}$ \\ ${ }^{1}$ State Key Laboratory for Conservation and Utilization of Subtropical Agro-Bioresources, Nanning, China \\ ${ }^{2}$ School of Chemistry and Chemical Engineering, Guangxi University, Nanning, China \\ ${ }^{3}$ College of Engineering, Yongjiang University, Nanning, China \\ Email: pjyaogxu@126.cn
}

Received January 10, 2012; revised February 7, 2012; accepted March 5, 2012

\begin{abstract}
Novozym-435 Lipase-catalyzed transesterification of glucose with 11-dodecenoic ethyl ester in ionic liquids was investigated. The effect of substrate ratio, lipase content, and temperature on the activity and stability of lipase was also studied. The highest yield of sugar ester was obtained in 1-buty-3-methyl imidazolium tetrafluoroborate [Bmim][BF4] under such conditions as the reaction temperature of $55^{\circ} \mathrm{C}$, the enzyme concentration of $20 \mathrm{mg} / \mathrm{mL}$, the mole ratio of glucose/11-dodecenoic ethyl ester of 1:2, the water content of the system of $2 \%$, Lipase Novozym- 435 can use repeatedly 7 times. The structure of production was characterized by FTIR, HPLC, MS and NMR. The results show that the production is 6-O-(11-dodecenoic)-glucose ester.
\end{abstract}

Keywords: Ionic Liquids (ILs); 6-O-(11-Dodecenoic)-glucose Ester; Lipase; 11-Dodecenoic Ethyl Ester; Glucose

\section{Introduction}

Fatty acid sugar esters have been widely used as sweeteners and non-ionic surfactants in pharmaceuticals, cosmetics, and food industries because they are biodegradable, non-toxic, and non-irritaing [1-2]. Currently, chemical synthesis is the major industrial method for sugar ester production. Existing chemical approaches have some obvious drawbacks, such as the low or non-selectivity for the site of estification, the requirement for protection and de-protection steps, and product purification difficulties. Since the discovery of lipase-catalyzed sugar esterification in organic solvents by the A. M. Klibanov [3] group in 1980's, the bio-catalytic synthesis of sugar esters has been studied extensively. This method of synthesis has the advantage of producing regio- and stereo-specific products under mild reaction condition [4-6]. However, the organic solvents used in the enzymatic synthesis (e.g. pyridine) are toxic, volatile, and non-reusable. Moreover, most enzymes are quickly inactivated in the organic solvents [7]. To overcome these limitations, researchers have been seeking a reaction medium that can dissolve both polar-sugars and nonpolar fatty acids, while at the mean time leaving the catalytic activity of the enzyme intact $[8,9]$.

During the past decade, ionic liquids (ILs) have been

*This research was supported by Guangxi Natural Science Foundation (No. 0991004). found to be suitable (even improved) replacements for the organic solvents in many reactions, ILs consist of anions and cations that have liquid properties at room temperature [10]. Compared to organic solvents, ionic liquids are relatively non-toxic, and do a better job of maintaining the enzyme activity and good substrate solubility [11-14]. Today, ILs have becomes a more attractive possibility as a reaction medium for used in selective acylation of carbohydrates.

In this paper, Novozym-435 Lipase was used as the catalyst for the synthesis of dodecenoic-glucose ester in ILs, using glucose and 11-dodecenoic ethyl ester as the substrates. The effects of substrate ratio, lipase content, and temperature on reaction yield were studied. The purified product was characterized by HPLC, MS and NMR. The results demonstrated that ILs can be used as a "greener" solvent for sugar esterification, and illustrate the advantages of ILs vs. organic solvents for the specific lipase used for sugar ester synthesis.

\section{Materials and Methods}

\subsection{Materials}

Candida antarctica lipase B(CAL-B) were purchased from Sigma, lipase Novozym-435 and lipase Lipozyme TLIM were purchased from Novo Nordisk. TOKYO Chemical Industry Co. Ltd. was the source of 11-dodecenoic ethyl ester (99\%). while the Silica gel G and H 
were obtained from Qingdao Haiyang Chemical Co. Ltd. Ethyl acetate, acetonitrile, ethyl ether, toluene, methanol, and petroleum ether were all of analytical grade from commercial sources.

\subsection{Apparatus}

Waters HPLC system (Waters 600E, USA) equipped with a ELSD detector (Alltech 2000, USA); Rotatory eva- porator (Ya Rong, Shang Hai); Shaking Incubator (ZH- WY211B, Shang Hai); Agilent 1100 LC/MSD System (Trap SL, USA); NMR spectrometer(Bruker Avance AV $500 \mathrm{MHz}$, Switzerland).

\subsection{The Synthesis of ILs [Bmim] $\left[\mathrm{BF}_{4}\right]$}

$87.3 \mathrm{~g}(0.5 \mathrm{~mol})[\mathrm{Bmim}][\mathrm{Cl}]$ and $54.9 \mathrm{~g}(0.5 \mathrm{~mol}) \mathrm{NaBF}_{4}$ were mixed in the flask with $300 \mathrm{ml}$ acetone, the reaction was carried out with magnetic stirring for $24 \mathrm{~h}$ at room temperature, reaction liquids was vacuum filtrated, acetone was removed by reduced pressure distillation. Reaction liquids was extracted many times until no precipitation was appeared after dropping $\mathrm{AgNO}_{3},[\mathrm{Bmim}][\mathrm{BF} 4]$ was collected. $78.3 \mathrm{~g}$ pale yellow ILs $[\mathrm{Bmim}]\left[\mathrm{BF}_{4}\right]$ were collected after carbon decolourization and vacuum drying.

\subsection{Enzymatic Reaction in ILs $[\mathrm{Bmim}]\left[\mathrm{BF}_{4}\right]$}

$5 \mathrm{mmol}(0.991 \mathrm{~g})$ glucose and a certain amount of 11dodecenoic ethyl ester were dissolved in $10 \mathrm{ml}$ ILs, respectively. A certain mass concentration of lipase was added to the liquids which was mixed in the shaking incubator for $1 \mathrm{~h}$, the reaction was carried out at various temperature, $220 \mathrm{rpm}$ for $48 \mathrm{~h}$, The course of the reaction was confirmed by TLC. Sample was analyzed by HPLC for determining the yield of glucose ester at the end of reaction. Various factors such as the reaction temperature, mole ratio of glucose/vinyl palmitate, water content of the system, enzyme and concentration were investigated for the yield of glucose ester.

The unreacted glucose was removed by vacuum filtration and enzyme was recycled. ILs and glucose ester were separated by extraction, when $[\mathrm{Bmim}]\left[\mathrm{BF}_{4}\right]$ was the reaction solution, toluene was the extractant. Glucose ester was separated by silicagel column chromatography with chloroform/methanol $(8 / 1, \mathrm{~V} / \mathrm{V})$ as eluant. The white dodecenoic-glucose ester was obtain after lyophilization.

\subsection{The Yield of Dodecenoic-Glucose Ester}

Purified 11-dodecenoic glucose ester was weighed exactly and dissolved in methanol (CP), the standard solution of $20 \mathrm{mg} \cdot \mathrm{mL}^{-1}, 40 \mathrm{mg} \cdot \mathrm{mL}^{-1}, 60 \mathrm{mg} \cdot \mathrm{mL}^{-1}, 80$ $\mathrm{mg} \cdot \mathrm{mL}^{-1}, 100 \mathrm{mg} \cdot \mathrm{mL}^{-1}$ were obtained, the peak area of standard solution were determined by HPLC, the stan- dard curve between peak area and concentration was obtained. The peak area of synthesis production was determined on the same condition, the concentration of sample was obtained from standard curve. The yield of synthesis production was calculated as flow:

$$
\begin{gathered}
\text { Yield } / \%=\frac{C x\left(\mathrm{mg} \times \mathrm{ml}^{-1}\right) \times 10 \mathrm{ml}}{M_{d g}\left(\mathrm{mg} \times \mathrm{mmol}^{-1}\right) \times 5 \mathrm{mmol}} \times 100 \% \\
M_{d g}=360
\end{gathered}
$$

\subsection{Methods of Instrumental Analysis}

The product was analyzed by both TLC and HPLC methods. In TLC analysis, silica gel $\mathrm{G}$ recoated thin-layer chromatography plates (Qingdao fine chemical factory, China) was used, Chloroform/methanol (8/1, each by volume) was used as the developing system. TLC bands were visualized by spraying with reagent $(10 \%$ sulfuric acid aqueous solution).

The HPLC analysis was performed using a HPLC system (Waters 600E, Waters, USA) equipped with a Diamonsil C18 column, a mobile phase consisting of methanol: water $(90: 10, \mathrm{v} / \mathrm{v})$ at a flow rate of $1 \mathrm{ml} / \mathrm{min}$. the injection volume was $10 \mu \mathrm{L}$ The eluant was analyzed with a light scattering detector (Alltech ELSD 2000) at $100^{\circ} \mathrm{C}$.

The electrospray ionization mass spectrometry (ESIMS) analysis was carried out on a Agilent 1100LC/MSD instrument (Agilent, Trap SL USA) with $\mathrm{N}_{2}$ gas flow-rate of $10 \mathrm{~L} / \mathrm{min}$, and at a temperature of $350^{\circ} \mathrm{C}$.

${ }^{1} \mathrm{H}$ NMR, ${ }^{13} \mathrm{C}$ NMR, ${ }^{1} \mathrm{H}-{ }^{1} \mathrm{H}$ COSY and ${ }^{13} \mathrm{C}-{ }^{1} \mathrm{H}$ HSQC spectra of the product were recorded on a Bruker Avance 500 spectrometer, using samples dissolved in $\mathrm{CD}_{3} \mathrm{OD}$.

\section{Results}

\subsection{Three Lipase Activities in Different ILs}

Three enzymes were tested in our reaction system, using $[\mathrm{Bmim}]\left[\mathrm{BF}_{4}\right]$ as the reaction media. Figure 1 showed the final yield of the sugar ester with each of the enzymes. It is clear that lipase Novozym-435 gave the highest yield

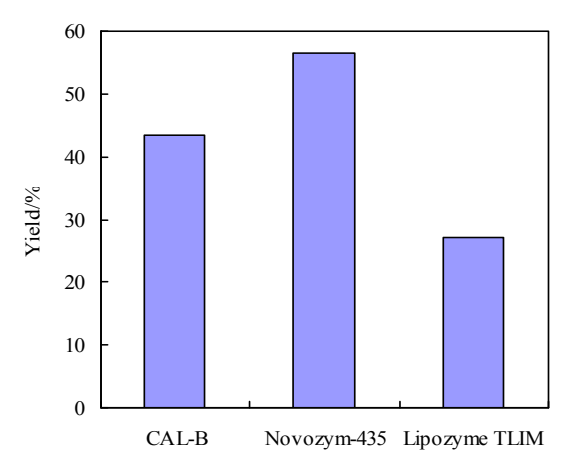

Figure 1. Effect of enzymes to the yield of glucose ester. 
(51.6\%), with lipase CAL-B and lipase Lipozyme TLIM yielding significantly less $(43.5 \%$ and $36.1 \%$, respectively). Therefore, the lipase Novozym- 435 was used in the subsequent reactions.

Three ionic liquids were tested in our reaction system as the reaction media, using Novozym-435 as the enzymes. Figure 2 showed the final yield of the sugar ester with each of the ionic liquids. It is clear that ILs [Bmim] $\left[\mathrm{BF}_{4}\right]$ gave the highest yield $(53 \%)$, with $[\mathrm{Bmim}][\mathrm{Cl}]$ and $[\mathrm{Bmim}]\left[\mathrm{PF}_{6}\right]$ yielding significantly less $(31 \%$ and $20 \%$, respectively). Therefore, the ILs $[\mathrm{Bmim}]\left[\mathrm{BF}_{4}\right]$ was used in the subsequent reactions as the reaction media.

\subsection{Optimization of Reaction Conditions}

The effects of system water content, temperature, substrate ratio, lipase content and re-use of the ionic liquid on the activity and stability of Novozym-435 lipase were studied.

In our research, the effect of water content was investtigated, the results in Figure 3 showed that the water content of $2 \%$ was the best condition for synthesizing glucose ester, thus, the water content of $2 \%$ was confirmed in the reaction system.

Figure 4 shows the effect of temperature on the reactions yield, showing that the yield of dodecenoic-glucose ester was highest when the temperature was at $55^{\circ} \mathrm{C}$. These data suggest that the enzyme loses its activity at

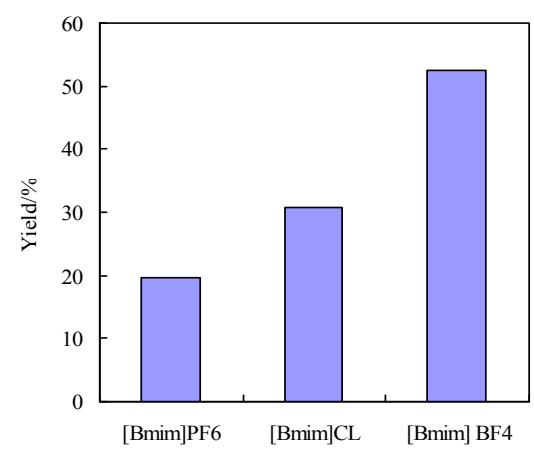

Figure 2. Effect of ILs to the yield of glucose ester.

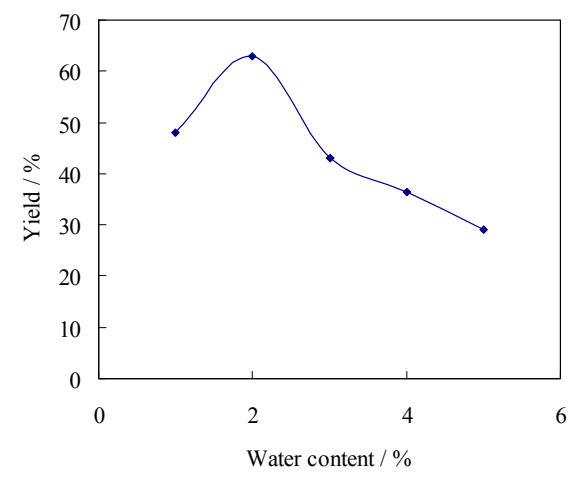

Figure 3. The effect of watercontent on the synthesis of glucose ester.

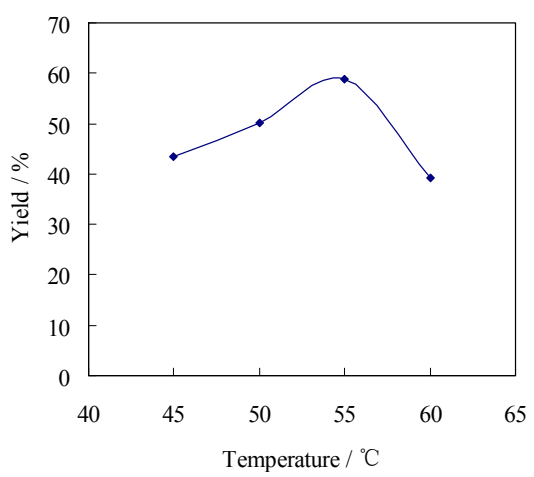

Figure 4. The effect of temperature on the synthesis of glucose ester.

higher temperatures. Therefore, $55^{\circ} \mathrm{C}$ was taken as the optimum temperature for this Novozym-435 reaction system.

The Effect of Mole Ratio of Glucose/Vinyl Palmitate on Transesterification

The influence of mole ratio of glucose/11-dodecenoic ethyl ester on the yield was shown in Figure 5, when the ra- tio was $2: 1$, the yield reached $62 \%$, then the best ratio of glucose and 11-dodecenoic ethyl ester was confirmed.

The influence of the enzyme concentration was indicated in Figure 6, when the concentration of enzyme increased from $10 \mathrm{mg} \cdot \mathrm{mL}^{-1}$ to $20 \mathrm{mg} \cdot \mathrm{mL}^{-1}$, the yield of glucose ester raised, then increase the concentration of enzyme, the yield decreased. This probably because some monoester transformed to diester further, so, the enzyme concentration of $20 \mathrm{mg} \cdot \mathrm{mL}^{-1}$ was appropriate.

Because Novozym-435 is one of immobilized enzyme, reutilization is important for reducing the production cost. In this study, Novozym- 435 can be reused 7 times, the yield decreased at the 8th obviously as indicated in Figure 7.

\subsection{Characterization of Reaction Product}

The FT-IR spectra of glucose, 11-dodecenoic ethyl ester and the reaction product are shown in Figure 8, The vibrations absorbance of-OH $\left(3307 \mathrm{~cm}^{-1}\right)$, C-O-C (1169 $\left.\mathrm{cm}^{-1}\right)$ and $\mathrm{C}=\mathrm{O}\left(1732 \mathrm{~cm}^{-1}\right), \mathrm{C}=\mathrm{C}\left(1633 \mathrm{~cm}^{-1}\right)$ in the product indicate that transesterification between glucose and 11-dodecenoic ethyl ester has occurred.

HPLC analysis of the purified reaction product (Figure 9) shows only a single peak, and its ESI-MS spectrum (Figure 10) shows the principal signal at $383.2 \mathrm{~m} / \mathrm{z}$ $[\mathrm{M}+\mathrm{Na}]^{+}$. This is consistent with the molecular weight (360) of dodecenoic-glucose ester $\left(\mathrm{C}_{18} \mathrm{H}_{32} \mathrm{O}_{7}\right)$.

The ${ }^{1} \mathrm{H}$ and ${ }^{13} \mathrm{C}$ NMR signals of the purified product were assigned by comparison of the spectra of the product with the spectra of reactants (glucose and 11-dodecenoic ethyl ester) and by two-dimensional spectra, specifically ${ }^{1} \mathrm{H}-{ }^{1} \mathrm{H}$ COSY and ${ }^{1} \mathrm{H}-{ }^{13} \mathrm{C}$ HSQC (Figure 11). 


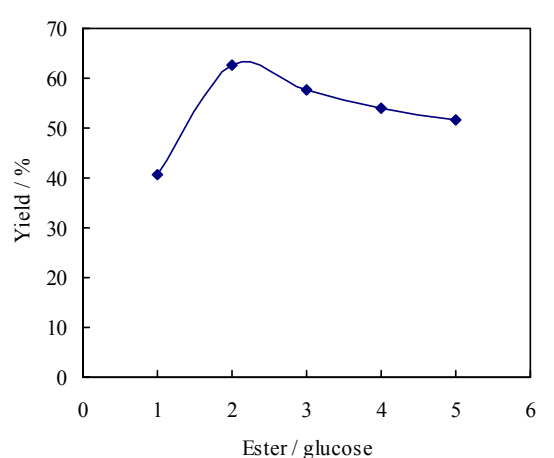

Figure 5. Effect of reaction ester/sugar dosage ratio to the yield of glucose ester.

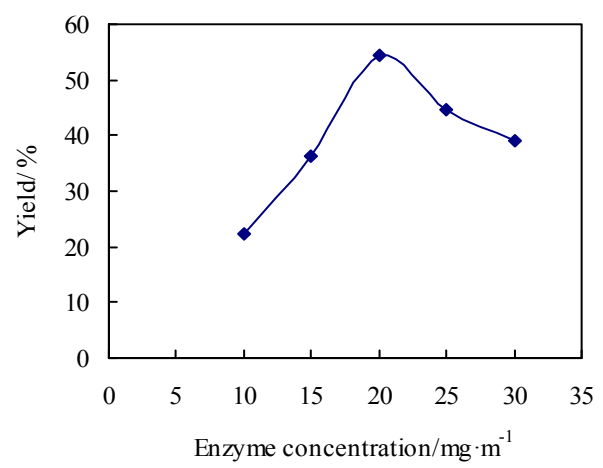

Figure 6. Effect of enzyme concentration to the yield of glucose este.

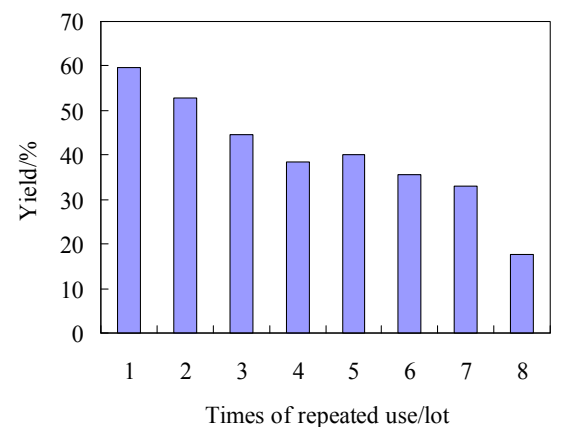

Figure 7. Effect on the yield of repeated use of enzyme.

Figure 11 shows the ${ }^{1} \mathrm{H}^{13} \mathrm{C}$ HSQC spectrum in the center, the proton spectrum in the top, and carbon spectrum in the left panel. The major proton-carbon crosspeaks were assigned and are labeled in the HSQC spectrum.

Table 1 gives the $1 \mathrm{H}$ and $13 \mathrm{C}$ chemical shifts of NMR signals in the product.

Because there are two configurations of $\alpha$ and $\beta$ in synthetic glucose pyranose ring, the $\mathrm{C}$ and $\mathrm{H}$ positions of synthetic products are marked using Greek letters and Arabic numbers, respectively, as shown in Figure 12.

It is clear that the signal of carbon 6 (C-6) of glucose has shifted down field to $64.43 \mathrm{ppm}(\alpha)$ or $64.53 \mathrm{ppm}(\beta)$, compared with the regular C-6 of glucose at $61.28 \mathrm{ppm}$, this indicate that the esterification has occurred on the

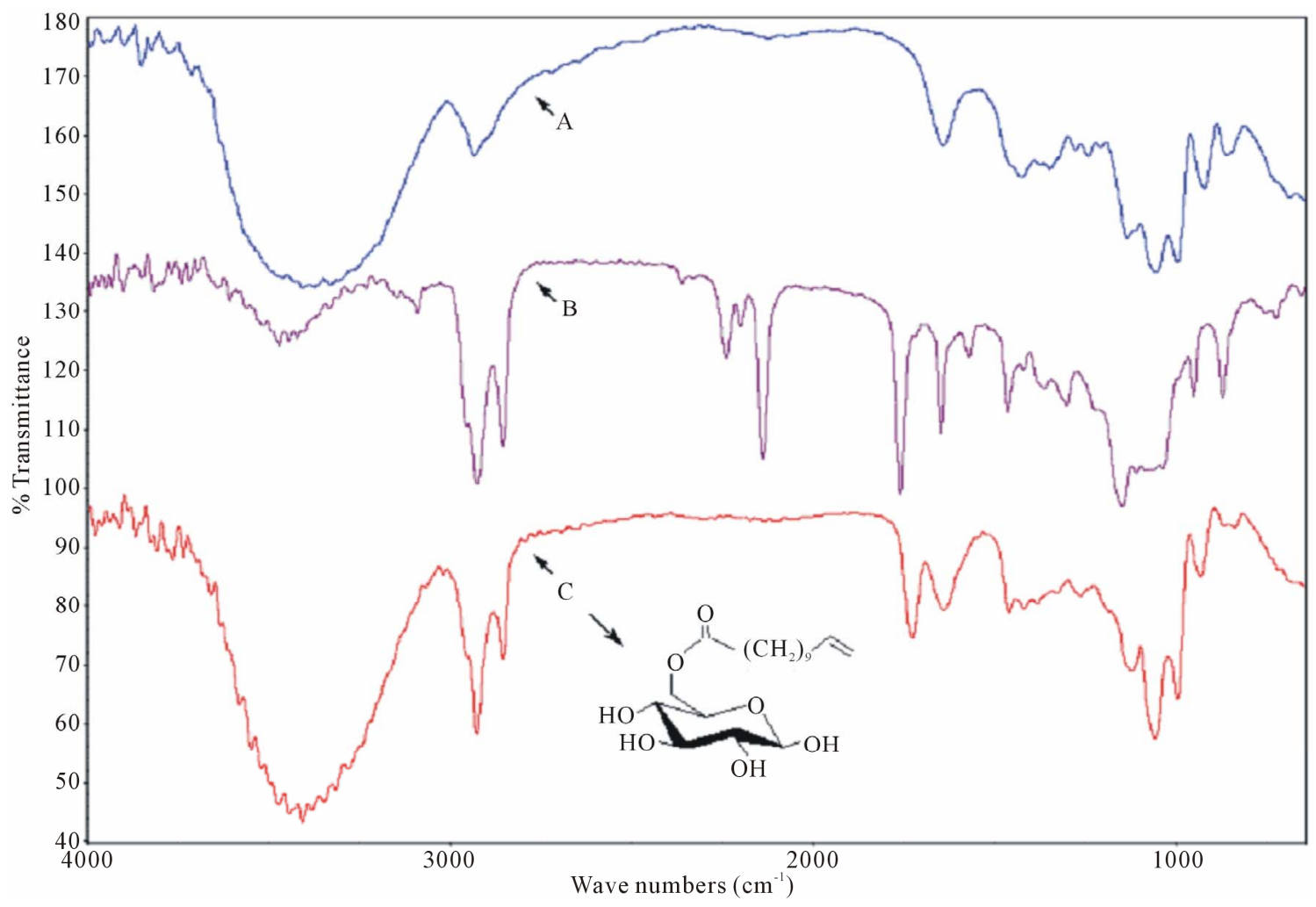

Figure 8. The FT-IR spectra of glucose (A), 11-dodecenoic ethyl (B) and synthetic products (C). 


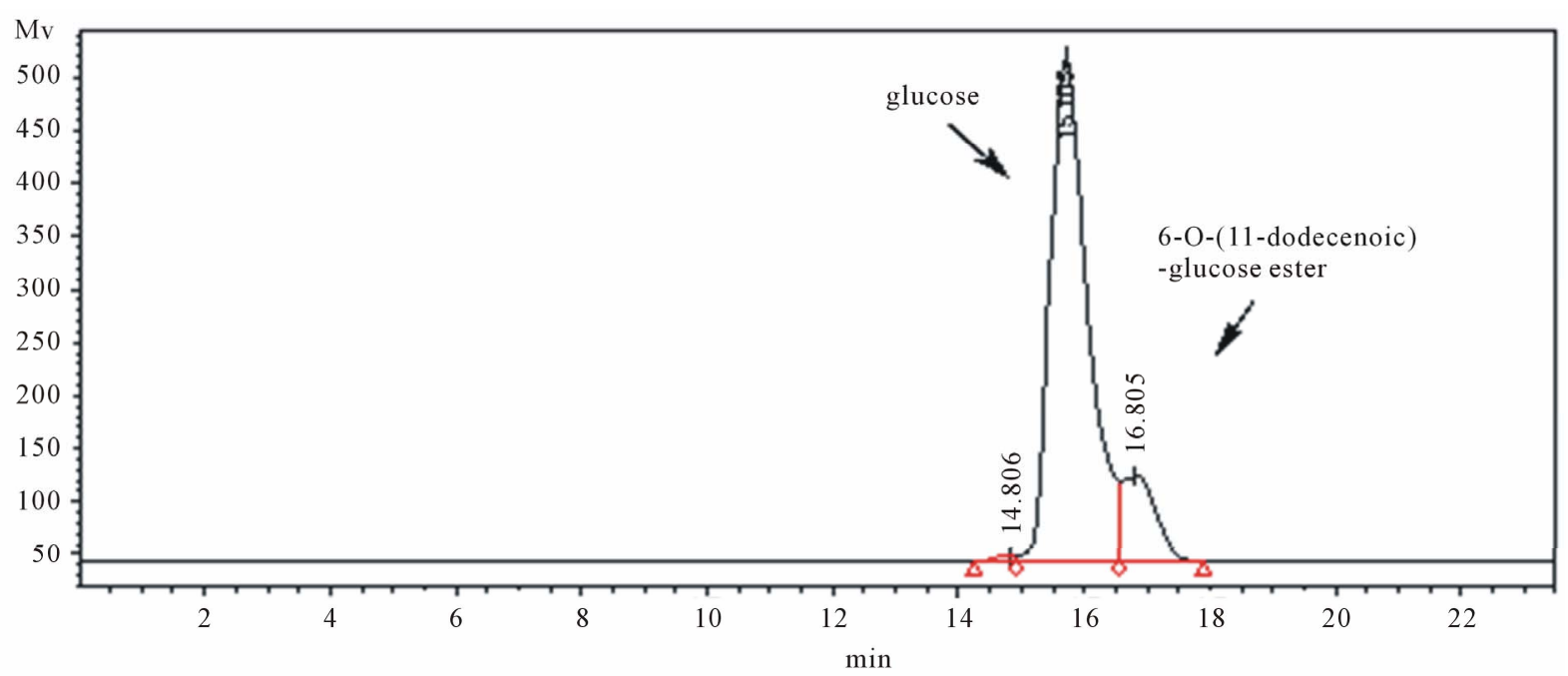

Figure 9. The HPLC spectrum of the sugar ester.

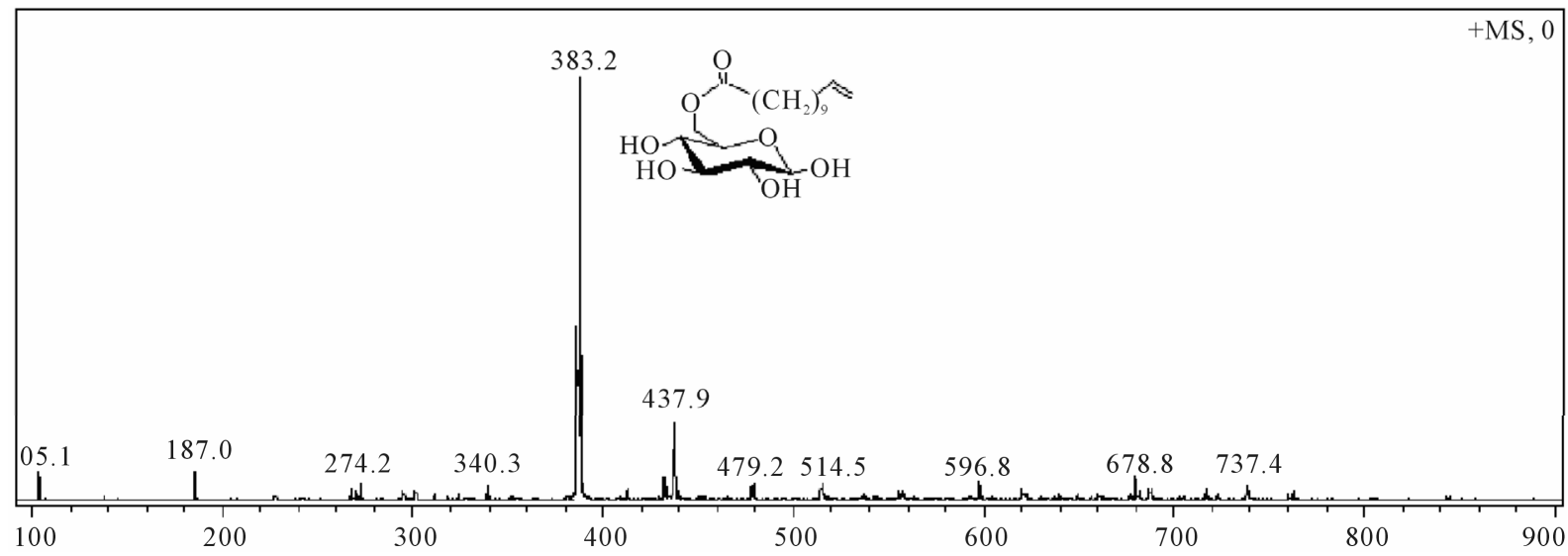

Figure 10. MS spectrum of the glucose ester.

Table 1. The ${ }^{1} \mathrm{H}$ and ${ }^{13} \mathrm{C}$ chemical shifts of NMR signals of the product in $\mathrm{CD}_{3} \mathrm{OD}$.

\begin{tabular}{|c|c|c|c|c|}
\hline \multirow{2}{*}{$\begin{array}{c}\text { Carbon-bit } \\
\text { glucosyl }\end{array}$} & \multicolumn{2}{|c|}{${ }^{13} \mathrm{C}$ NMR chemical shifts $\delta \mathrm{C}^{13} / \mathrm{ppm}$} & \multicolumn{2}{|c|}{${ }^{1} \mathrm{H}$ NMR chemical shifts $\delta \mathrm{H}^{1} / \mathrm{ppm}$} \\
\hline & $\alpha$-pyran & $\beta$-pyran & $\alpha$-pyran & $\beta$-pyran \\
\hline 1 & 93.93 & 97.76 & $4.84(1 \mathrm{H}, \mathrm{d}, 4.0 \mathrm{~Hz})$ & $4.56(1 \mathrm{H}, \mathrm{d}, 8.0 \mathrm{~Hz})$ \\
\hline 2 & 73.76 & 76.55 & $3.23(\mathrm{~m})$ & $3.17(\mathrm{SSS} \mathrm{H}, \mathrm{dd}, 8.8 \mathrm{~Hz}, 8.0 \mathrm{~Hz})$ \\
\hline 3 & 74.49 & 78.56 & $3.58(1 \mathrm{H}, \mathrm{dd}, 9.6 \mathrm{~Hz}, 9.6 \mathrm{~Hz})$ & $3.39(\mathrm{~m})$ \\
\hline 4 & 72.01 & 72.16 & $3.25(\mathrm{~m})$ & $3.25(\mathrm{~m})$ \\
\hline 5 & 70.58 & 75.22 & $3.87(1 \mathrm{H}, \mathrm{ddd}, 10.0 \mathrm{~Hz})$ & $3.44(1 \mathrm{H}, \mathrm{ddd}, 9.2 \mathrm{~Hz})$ \\
\hline 6 & 64.43 & 64.53 & $\begin{array}{l}4.34(1 \mathrm{H}, \mathrm{dd}, 12.0 \mathrm{~Hz}) \\
4.21(1 \mathrm{H}, \mathrm{dd}, 12.0 \mathrm{~Hz})\end{array}$ & $\begin{array}{l}4.56(1 \mathrm{H}, \mathrm{dd}, 12.0 \mathrm{~Hz}) \\
4.37(1 \mathrm{H}, \mathrm{dd}, 12.0 \mathrm{~Hz})\end{array}$ \\
\hline olefinic link $\omega 1$ & \multicolumn{2}{|c|}{121.37} & $\omega 1 \alpha: 4.94(\mathrm{~m})$ & $\omega 1 \beta: 4.87(\mathrm{~m})$ \\
\hline olefinic link $\omega 2$ & \multicolumn{2}{|c|}{142.40} & \multicolumn{2}{|c|}{$5.24(\mathrm{~m})$} \\
\hline $\mathrm{CH}_{2}$ chain $\left(\mathrm{C}_{3}-\mathrm{C}_{11}\right)$ & \multicolumn{2}{|c|}{$30.08,30.19,30.24,30.42,30.45,30.61,30.72$} & \multicolumn{2}{|c|}{1.30 (br. m) } \\
\hline$\alpha-\mathrm{C}$ & \multicolumn{2}{|c|}{34.98} & \multicolumn{2}{|c|}{$2.27(\mathrm{t})$} \\
\hline$\beta$-C & \multicolumn{2}{|c|}{26.09} & \multicolumn{2}{|c|}{$1.60(\mathrm{t})$} \\
\hline carbonyl-C & \multicolumn{2}{|c|}{175.51} & & \\
\hline
\end{tabular}




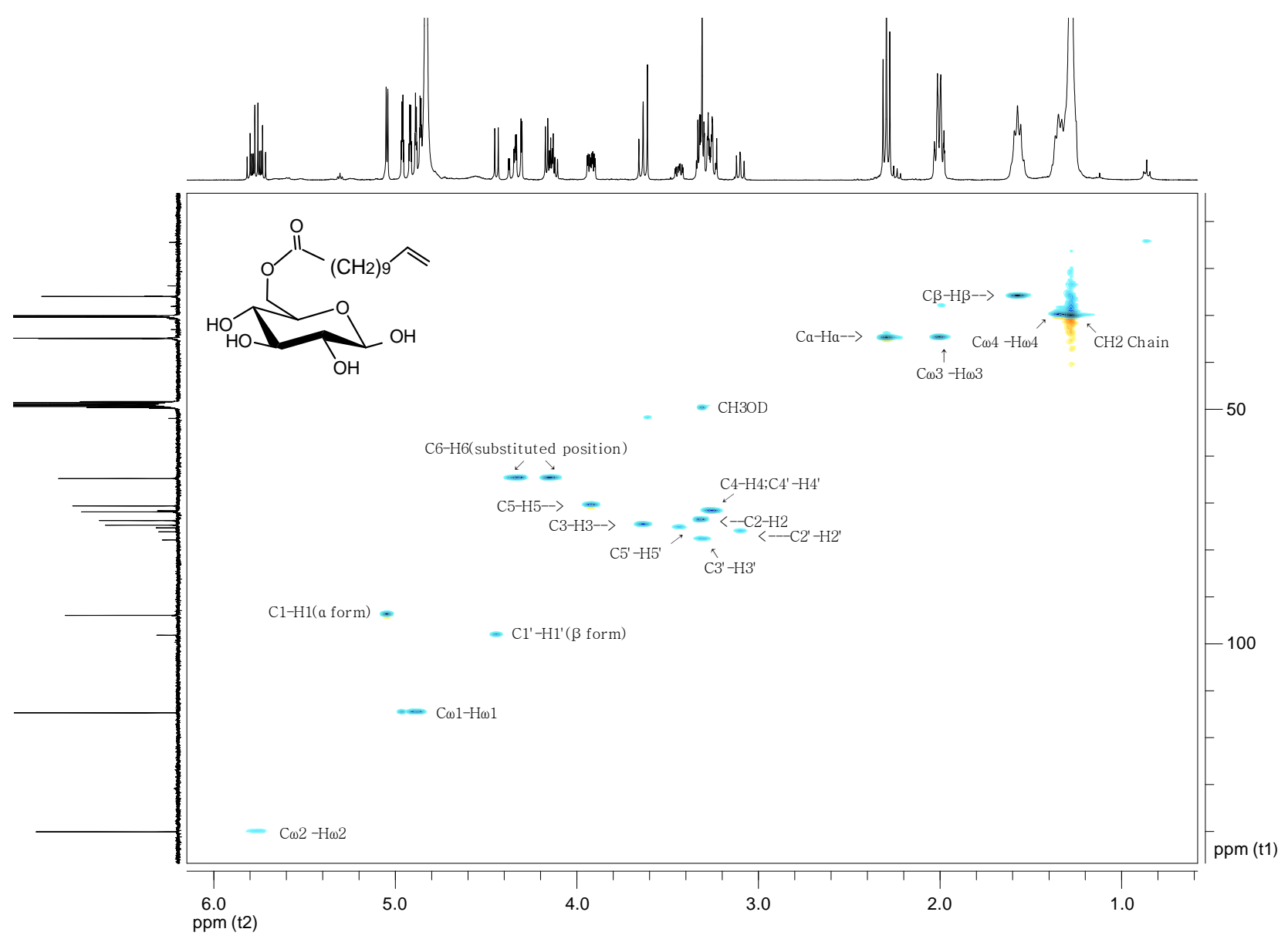

Figure 11. ${ }^{1} \mathrm{H}-{ }^{13} \mathrm{C}$ HSQC spectrum(in CD3OD)of the glucose monoester.
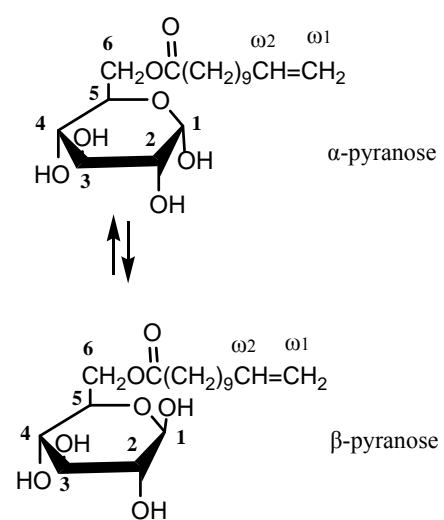

Figure 12. The Configuration and mark of the Synthetic products.

hydroxyl group of carbon 6 (6-OH) of glucose.

Taking all of these data into consideration, the reaction product was determined to be 6-O-(11-dodecenoic)glucose ester, with the structure shown in Figure 13, where the numbers denote the NMR assignments in Table 1.

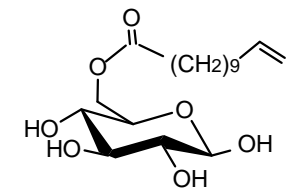

Figure 13. The structure of 6-0-(11-dodecenoic)-glucose ester.

\section{Discussion}

Enzyme activities in ILs (e.g. [Bmim] $\left[\mathrm{BF}_{4}\right]$ or [Bmim] $\left[\mathrm{BF}_{6}\right]$, were reported controversially for transesterification [15]. In the current investigation, three ionic liquids were tested in our reaction system as the reaction media, using Novozym- 435 as the enzymes. Then three enzymes were tested in our reaction system, using $[\mathrm{Bmim}]\left[\mathrm{BF}_{4}\right]$ as the reaction media.The results showed that Novozym435 Lipase-catalyzed transesterification of glucose with 11-dodecenoic ethyl ester can take place in ILs [Bmim] $\left[\mathrm{BF}_{4}\right]$.

The glucose transesterification was shown to occur at the 6-OH of the sugar ring as illustrated in the following scheme. 


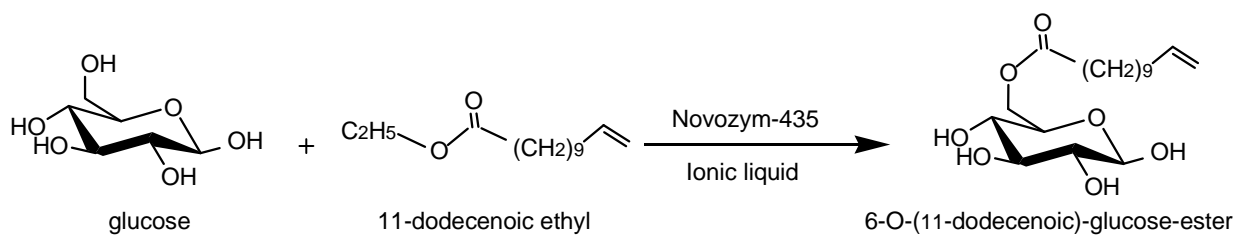

The lipase-catalyzed reaction was monitored by TLC and HPLC methods, showing that lipase Novozym-435 had catalyzed a good region-selectivity esterification of glucose in this IL system. The 6-hydroxyl substitution of glucose monoester was the principal product, together with the advantage of easy remove and re-use of the ionic liquid, these really made the following separation and purification of the product to be much quicker and easier.

We have reported previously that in organic solvents, many lipase enzymes, including CAL-B, Novozym-435 and others, tend to selectively catalyze the O-6-glucose selected esterification $[16,17]$. Comparing those results with the current results, it is clear that Novozym-435 lipase in the ILs has the same regional selectivity as it did in organic solvents.

Ionic liquids (ILs) are organic salts that completely constituted by the ions and liquid state at room temperature or near room temperature. Their non-volatile character and environmentally friendly make them attractive alternatives for volatile organic solvents. In chemical reaction, ILs exhibit excellent characteristics including the ability to dissolve polar and non-polar organic compounds. The choice of solvent for the esterifications of glucose is very difficult, because one reactant is polar (glucose), the other is non-polar (fatty acid vinyl ester or fatty acid), and the product is amphiphilic (glucose ester). Most ILs possess both a hydrophilic ionic head and a hydrophobic organic chain. Therefore, ILs may be good solvents for the esterifications of glucose. Moreover,the ILs seems to be more enzyme-compatible in that it allows more substrate (e.g. sugar) to access the active site of the enzyme. The ILs has the added advantage of easy removal and re-use, thereby simplifying, facilitating, and "greening" the reaction.

\section{Conclusions}

In this paper, Novozym-435 Lipase-catalyzed transesterification of glucose with 11-dodecenoic ethyl ester in ionic liquids was investigated. In the current investigation, three ionic liquids were tested in our reaction system as the reaction media, using Novozym-435 as the enzymes. The results showed that $[\mathrm{Bmim}]\left[\mathrm{BF}_{4}\right]$ gave the highest yield. Three enzymes were tested in our reaction system, using $[\mathrm{Bmim}]\left[\mathrm{BF}_{4}\right]$ as the reaction media. The results showed that lipase Novozym-435 gave the highest yield and stability in this system.
Then we studied the optimization of transesterification conditions by lipase Novozym-435 activities in ILS $[\mathrm{Bmim}]\left[\mathrm{BF}_{4}\right]$. The effect of substrate ratio, lipase content, and temperature on the activity and stability of lipase was also studied. The highest yield of sugar ester was obtained in 1-buty-3-methyl imidazolium tetrafluoroborate $[\mathrm{Bmim}][\mathrm{BF} 4]$ under such conditions as the reaction temperature of $55^{\circ} \mathrm{C}$, the enzyme concentration of $20 \mathrm{mg} / \mathrm{mL}$, the mole ratio of glucose/11-dodecenoic ethyl ester of $1: 2$, the water content of the system of $2 \%$, Lipase Novozym-435 can use repeatedly 7 times. The structure of production was characterized by FTIR, HPLC, MS and NMR. The results show that the production is 6-O-(11dodecenoic)-glucose ester.

\section{Acknowledgements}

This work was supported by Guangxi Natural Science Foundation (No. 0991004).

\section{REFERENCES}

[1] M. V. Flores, K. Naraghi, J. M. Engasser and P. J. Halling, "Influence of Glucose Solubility and Dissolution Rate on the Kinetics of Lipase Catalyzed Synthesis of Glucose Laurate in 2-Methyl 2-Butanol," Biotechnology and Bioengineering, Vol. 78, No. 7, 2002, pp. 814-820. doi: $10.1002 /$ bit. 10263

[2] J. F. Kennedy, H. Kumar, P. S. Panesar, S. S. Marwaha, R. Goyal, A. Parmar and S. Kaur, "Enzyme-Catalyzed Regioselective Synthesis of Sugar Esters and Related Compounds," Journal of Chemical Technology \& Biotechnology, Vol. 81, No. 6, 2006, pp. 866-876. doi: $10.1002 /$ jetb. 1473

[3] M. Therisodt and A. M. Klibanov, "Facile Enzymatic Preparation of Monoacylated Sugars in Pyridine," American Chemical Society, Vol. 108. No. 18, 1986, pp. 5638-5640.

[4] F. Ganske and U. T. Bornscheuerv, "Optimization of Lipase-Catalyzed Glucose Fatty Acid Ester Synthesis in a Two-Phase System Containing Ionic Liquids and t-Bu$\mathrm{OH}$," Journal of Molecular Catalysis B: Enzymatic, Vol. 36, No. 1-6, 2005, pp. 40-42. doi:10.1016/j.molcatb.2005.08.004

[5] S. Riva, J. Chopineau, A. P. G. Kieboom and A. M. Klibanov, "Protease-Catalyzed Regioselective Esterification of Sugars and Related Compounds in Anhydrous Dimethylformamide," Journal of the American Chemical Society, Vol. 110, No. 2, 1988, pp. 584-589. doi: $10.1021 / \mathrm{ja} 00210 \mathrm{a} 045$

[6] H. S. Soedjak and J. E. Spradlin, "Enzymatic Transesterification of Sugars in Anhydrous Pyridine," Biocatalysis and 
Biotransformation, Vol. 11, No. 3, 1994, pp. 241-248. doi:10.3109/10242429408998144

[7] F. J. Plou, M. A. Cruces, M. Bernable, M. Martin-Loma, J. L. Parra and A. Ballesteros, "Enzymatic Synthesis of Partially Acylated Sucrosesa," Annals of the New York Academy of Sciences, Vol. 750, 1995, pp. 332-337. doi:10.1111/j.1749-6632.1995.tb19976.x

[8] J. O. Rich, B. A. Bedell and J. S. Dordick, "Controlling Enzyme-Catalyzed Regioselectivity in Sugar Ester Synthesis," Biotechnology and Bioengineering, Vol. 45, No. 5, 1995, pp. 426-434. doi:10.1002/bit.260450507

[9] Z. Yang and W. B. Pan, "Ionic Liquids: Green Solvents for Nonaqueous Biocatalysis," Enzyme and Microbial Technology, Vol. 37, No. 1, 2005, pp. 19-28. doi:10.1016/j.enzmictec.2005.02.014

[10] N. Kimizuka and T. Nakashima, "Spontaneous SelfAsembly of Glycolipid Bilayer Membranes in SugarPhilic Ionic Liquids and Formation of Ionogels," Langmuir, Vol. 17, No. 22, 2001, pp. 6759-6761. doi:10.1021/la015523e

[11] R. P. Swatloski, S. K. Spear, J. D. Holbrey and R. D. Rogers, "Dissolution of Cellose with Ionic Liquids," Journal of the American Chemical Society, Vol. 124, No. 18, 2002 , pp. 4974-4975. doi: $10.1021 / \mathrm{ja} 025790 \mathrm{~m}$
[12] D. R. MacFarlane, J. Golding, S. Forsyth, M. Forsyth and G. B. Deacon, "Low Viscosity Ionic Liquids Based on Organic Salts of the Dicyanamide Anion," Chemical Communications, No. 16, 2001, pp. 1430-1431. doi:10.1039/b103064g

[13] S. A. Forsyth, D. R. MacFarlane, R. J. Thomson and M. V. Itzstein, "Rapid, Clean, and Mild O-Acetylation of Alcohols and Carbohydrates in an Ionic Liquid," Chemical Communications, No. 7, 2002, pp. 714-715. doi: $10.1039 / \mathrm{b} 200306 \mathrm{f}$

[14] S. A. Forsyth and D. R. MacFarlane, "1-Alkyl-3-Methylbenzotriazolium Salts: Ionic Solvents and Electrolytes," Journal of Materials Chemistry, Vol. 13, No. 10, 2003, pp. 2451-2456. doi:10.1039/b307931g

[15] G. J. Huang, T. Wang, P. J. Yao and Y. A. Wei. "Studies on Enzymatic Synthesis of 6-O-Lauroylsucrose in Ionic Liquids," Journal of Guangxi University: Natural Science Edition, Vol. 35, No. 3, 2010, pp. 455-461.

[16] Y. Z. H. Wang, Q. L. Li, W. Yue, P. J. Yao and Y. A. Wei, "6-O-(10-Undecylenoyl)-D-Glucose: Controlled Enzymatic Synthesis and Structure Elucidation by ${ }^{1} \mathrm{H}$ and ${ }^{13}$ C NMR," Advanced Materials Research, Vol. 396-398, 2012, pp. 1318-1324. doi:10.4028/www.scientific.net/AMR.396-398.1318 